\title{
Construção e enfrentamentos da tradição das serenatas e serestas em Conservatória
}

\author{
MARIA GORETT DE OLIVEIRA SILVA DE CASTRO \\ Universidade Federal Rural do Rio de Janeiro, Rio de Janeiro, Brasil
}

DOI 10.11606/issn.2316-9133.v28i1p184-200

\begin{abstract}
resumo Este artigo tem como objetivo apresentar algumas configurações das manifestações das serenatas e serestas que se realizam em Conservatória, um pequeno distrito que tem o registro dessas manifestações desde o século XIX. Contudo, começou a ser alvo de interesse em registro como patrimônio cultural imaterial agora no século XXI. O ponto de abordagem foi o desenvolvimento dessa manifestação ao longo do tempo, as construções que foram realizadas em torno de conceitos como memória e tradição. E, como um grupo de seresteiros foi alicerçando um movimento que procura preservar essas tradições. Dentro do contexto, alguns conflitos e disputas, processos de silenciamento e apagamento de elementos constituintes do processo de construção dessa tradição. Apresenta ainda o interesse em fazer a patrimonialização da manifestação da serenata, bem como as relações de interação com o turismo e outras manifestações locais.
\end{abstract}

palavras-chaves Serenatas; serestas; tradição; memória; patrimônio.

Constructing and fighting for serenatas and serestas traditions in

\section{Conservatória}

abstract This article aims to present some settings of the manifestations of serenatas and serestas which take place in Conservatória, a small district which has the record of these demonstrations since the 19th century. However, it began to be targeted by interest in record as intangible cultural tradition now in the 21st century. The point of approach was the development of this expression over time, the buildings were carried out around concepts such as memory and tradition. And, as a group of sersteiros was building on a movement that seeks to preserve these traditions. Within the context, some conflicts and disputes, mute and deletion processes components of the construction process of this tradition. Still shows the interest in the having heritage of the manifestation of the serenata, as well the relations of interaction with tourism and other local events.

keyword: serenatas; serestas; tradition; memory; heritage. 


\section{Introdução}

Serenatas e serestas ${ }^{1}$ são manifestações que ocorrem em todo o país, mas ganhou especificidade no distrito de Conservatória, região serrana do Rio de Janeiro. De acordo com o censo de 2010, o distrito de Conservatória (Valença), tem uma população aproximada de 4.150 moradores fixos, e conta também com uma quantidade de moradores flutuantes vindos de cidades próximas, como Rio de Janeiro, Juiz de Fora, Barra Mansa, Volta Redonda, entre outras. São pessoas engajadas nos grupos musicais que se apresentam semanalmente no distrito e alugam ou adquirem propriedades para assim poderem participar das atividades. Nos finais de semana, o vilarejo recebe, em média, dois mil visitantes que vão à busca de assistir as diversas atrações musicais oferecidas, seja por grupos autônomos, sem fins lucrativos, ou por bares, restaurantes, hotéis e casas de show que exploram comercialmente a demanda de fãs da música brasileira.

A notoriedade de Conservatória sobrevém da construção das atividades seresteiras ao longo de décadas. A essa construção, designada 'Movimento Seresteiro de Conservatória' se convencionou chamar, entre seus agentes, tradição: "A primeira canção a ser cantada na serenata, por tradição, é de Cândido das Neves.”, “... em manter a tradição das serenatas”. Essa denominação é usada não apenas pelos integrantes e moradores, mas também por pessoas que interagem com a manifestação, sejam visitantes ou pesquisadores de diversas áreas. A aproximação com o conceito sociológico é devida à auto qualificação do movimento por ser um grupo com o objetivo de preservação do estilo musical romântico brasileiro e de reivindicar para essa manifestação o caráter de tradição local e patrimônio cultural.

Meu primeiro contato com as manifestações ocorreu num passeio turístico ao local. As referências que tinha eram apenas das práticas em si e não imaginava que encontraria um objeto de pesquisa. Percebi, contudo, a possibilidade de explorar essas práticas como objeto de pesquisa. Assim, já nesse primeiro momento procurei informações sobre a existência de trabalhos de pesquisa sobre o local e como ocorriam as serestas e serenatas. Foram poucas informações obtidas, mas o interesse me levou à elaboração do projeto para ingressar no curso de mestrado da Universidade Federal Rural do Rio De Janeiro (UFRRJ). Com o êxito do ingresso passei a retornar ao distrito para realizar o trabalho de campo, acompanhando sempre tanto serestas como serenatas. Isso possibilitou perceber uma miríade de aspectos que envolvem essas manifestações, dos quais alguns serão ser referidos nesse artigo.

Num primeiro momento foquei os aspectos do desenvolvimento ritual das serenatas, mas percebi outras abordagens que poderia explorar e serem mais significativa ao trabalho e assim fui ampliando para outras análises. Meus primeiros interlocutores foram alguns seresteiros do movimento que se dispuseram, com muita gentileza, a informar a história das manifestações e seus ingressos no grupo. Vale destacar que a maioria deles é de aposentados,

\footnotetext{
${ }^{1}$ Os termos têm significados diferentes. Segundo o pesquisador, compositor e radialista, Paulo Tapajós (MAGNO, 2015) serestas são execuções musicais em espaços fechados, uma mistura de sarau e serenata; já as serenatas são concertos no sereno.
} 
oriundos de profissões diversas: engenheiros, contadores, administradores, corretores, professoras, donas de casa, médico e outras. Em suas narrativas contam que foram assistir as manifestações, se encantaram e retornaram outras vezes, até serem chamados ou incentivados a cantar, passando a fazer parte do grupo. Poucos são moradores locais, mas vão constantemente, quase semanalmente, para participar das apresentações. Logo passei também a interagir com moradores, comerciantes e visitantes que forneceram informações substanciais à pesquisa.

O que pretendo neste artigo é apresentar partes significativas da trajetória da construção e formas de preservação dessa tradição que abarca processos de formação de simbolismos, significações, ressignificações e apagamentos de memórias desenvolvidas na dissertação. O trabalho teve como base a etnografia realizada de parte do contexto conservatoriano, o qual incluiu, além das serestas e serenatas, outras atividades musicais. Entretanto, o foco está nestas duas manifestações, que consensualmente os diversos agentes do local creditam serem geradoras do que podemos denominar, tomando de empréstimo o termo de Grünewald utiliza para designar "espaços sociais onde ocorrem interações geradas pela atividade turística", uma "arena turística" com expressões musicais na qual Conservatória se tornou. (GRÜNEWALD, 1999, p.3)

$\mathrm{Na}$ vivência local existem pequenos contextos sociais: dos moradores, dos grupos envolvidos com as diversas expressões musicais, dos comerciantes, dos hoteleiros e dos visitantes. Cada qual com características e elementos próprios. Para além desses pequenos contextos sociais se percebe a utilização de elementos materiais, como a arquitetura dos casarios, coisas antigas, construções antigas (ponte, túnel, estação ferroviária, igreja) formando uma ambientação que é apropriada para elaboração de discursos e sentidos. Elementos da natureza também são utilizados nessa composição de ambientação: sol, lua, estrelas, borboletas, vagalumes, entre outros, fazem parte de composições de músicas, poemas, artefatos decorativos, artesanatos. Nesse arranjo de elementos encontramos um fluxo de coisas que Ingold (2012) chama de malha (meshwork): um ambiente com elementos diversos, no qual coisas da natureza, coisas materiais, relações sociais, valores e outros, se entrelaçam num processo de fluxo contínuo. A construção dessa ambientação, envolvendo processos sociais e natureza, privilegiando elementos musicais, engendrou no local algumas denominações quase sempre relacionadas à música: "Cidade das Serestas", "Capital Mundial das Serestas e Serenatas", "Pedacinho do Céu” e "Vila das Ruas Sonoras”. Essas denominações exemplificam como variados elementos da natureza, componentes do ambiente local, são usados e apropriados para compor a malha de significados que envolvem as serenatas e serestas e outras manifestações.

É preciso considerar na construção desse contexto a importância dos meios de comunicação de massa na divulgação do local e das serenatas. Essa construção se elabora alicerçada na memória e discursos nacionalistas que "estão sempre imbricados com os efeitos da mídia global” (HUYSSEN, 2000, p.17). Nas décadas de 1920 e 1930, já existia um grupo de seresteiros que saia esporadicamente, nos finais das noites a cantarolar pelas ruas desertas. 
Assim, aos poucos, o lugarejo foi se tornando conhecido também pelas serenatas. A partir da década de 1960, ganhou exposição em revistas, guias turísticos e matérias de jornais sobre lazer e turismo ${ }^{2}$. Porém, uma divulgação bastante expressiva ocorreu quando suas ruas e casarios foram usados como cenário para novelas de época, expandindo conhecimento de sua existência pelo país e até internacionalmente.

Atualmente, com as novas tecnologias midiáticas a divulgação ampliou e criou oportunidades para a criação de sites informativos de grupos diferentes, como: seresteiros, das outras manifestações, dos hotéis e pousadas, e páginas de fãs se formaram no Facebook. Enfim, diversas possibilidades que as redes sociais permitem. Em 2014, um jovem, criador técnico, locutor e apresentador, e um seresteiro, produtor e apresentador, elaboraram na internet $A$ Rádio Sarau, sediada em Conservatória ${ }^{3}$. O site da rádio proporciona informações sobre a cidade, sobre a história de Conservatória, alguns pontos turísticos, eventos e a promoção de alguns artistas locais. E, como rádio, se pode ouvir músicas românticas brasileiras e a narração de parte das informações visualizadas no site.

Quando faço referências à Conservatória me refiro ao centro do distrito, onde ocorrem as manifestações e onde se situam alguns monumentos, igreja, bares, restaurantes, lojas e um museu. Ou como podemos inferir de narrativas com teor romântico, "onde a 'magia' acontece”. É chamado também de 'centro histórico', pois manteve a forma do projeto estrutural do distrito desde a construção e a arquitetura das casas, monumentos e praças predominantemente em estilo colonial, ainda que parte desse complexo tenha sido reconstruída a partir de um "estilo" reconhecido como colonial. Como apresenta Hobsbawm, edifícios e monumentos são as formas mais visíveis de uma interpretação histórica. São símbolos que podem provocar a fusão entre uma "tradição inventada" e o nacionalismo romântico (HOBSBAWM, 2017). Dessa ambientação decorrem categorias e noções incorporadas nas narrativas expressas por todos os agentes das manifestações: saudade, memórias, nostalgia, patrimônio, tradição, passado, romantismo.

O aspecto principal para o entendimento do contexto conservatoriano é a serenata. Como dito anteriormente elas já ocorriam no vilarejo nas primeiras décadas do século XX, contudo passaram a ter uma dimensão maior com a elaboração do "Movimento dos Seresteiros" ${ }^{4}$, na década de 1950 com a influência de dois irmãos: Joubert Cortines de Freitas (1921-2016) e José Borges de Freitas Neto (1922-2002), idealizadores e construtores desse movimento em Conservatória. Eles estiveram em Conservatória pela primeira vez em 1938. Ainda adolescentes, se incorporaram a um pequeno grupo de seresteiros que se reunia na

\footnotetext{
${ }^{2}$ A publicação de maior destaque, no período foi da revista O Cruzeiro, em 1968, com quatro páginas, "exaltando as características históricas, a tranquilidade, [...] com o título “Conservatória - 50 anos de Serenata." (MAGNO, 2015, p. 14). Material exposto na Casa da Cultura de Conservatória. Outras publicações do período: jornais, O Globo, Jornal do Brasil, O Estado de São Paulo, Jornal do Comércio; e em revistas como: Quatro Rodas, Isto é, National Geografic - Brasil e outras também expostas na Casa da Cultura.

${ }^{3}$ www.radiosarau.com.br

${ }^{4}$ A expressão 'movimento' é uma autodesignação do grupo, tendo sua utilização em algumas pesquisas sobre tema; como em Magno (2015), sobre as serenatas e Herschmann (2012) sobre o ativismo turístico musical local.
} 
casa de um deles - Emérito Silva (1911-1986), conhecido como Merito e após as reuniões saiam pelas ruas a cantar. Na segunda metade da década de 50, o pai, funcionário da rede ferroviária foi transferido para lá e família se estabeleceu por algum tempo, passando a se integrar à comunidade (Magno, 2015). O trabalho dos dois irmãos, junto ao grupo e a comunidade, elaborando práticas rituais novas, criando canções e poesias, direcionou para a conquista da liderança do grupo, sendo a principal realização a organização e sistematização das práticas.

Os irmãos, inicialmente, não eram residentes fixos de Conservatória, mas alugavam casas e eram constantes nas idas. No final da década de 1960, José Borges adquiriu a casa então alugada, na Rua Oswaldo Fonseca, 99. Nesta casa, posta à disposição pelo proprietário, se promoviam encontros dos seresteiros, moradores e turistas, para "guardar lembranças de músicas de tempos passados, pela rua" (Joubert e José Borges). Surgiu assim o Museu da Seresta e Serenata, inicialmente Museu da Seresta. Magno explica que "O nome 'museu' teria começado com uma brincadeira, como contou Adilon Alves Raposo ${ }^{5}$. Era a forma carinhosa como os filhos e sobrinhos dos 'coroas', que ali se reuniam, chamavam a casa, numa referência a faixa etária de seus frequentadores" (MAGNO, 2015, p. 37).

O nome, que começou como brincadeira acabou instituído pelas "práticas que o caracterizava como tal, considerando a definição do Departamento de Museus e Centros Culturais - IPHAN/Minc" (MAGNO, p.36). Assim, as serestas harmonizadas com as serenatas, anteriormente ocorrendo eventualmente, passaram ocorrer mais amiúde de forma organizada e ritualizada. Neste sentido, identificamos características descritas por Hobsbawm (1984) do processo de "invenção de tradições": a formalização e ritualização. O exemplo mais nítido da formalização dessas práticas foi a elaboração, em 1996, de um texto denominado Características Essenciais ${ }^{6}$, que posteriormente ficou conhecido por "Estatuto dos seresteiros". São sete normas não oficializadas; sem estatuto jurídico, nem contratos. Algumas de caráter reivindicatório da autonomia do grupo em relação a não vinculação com investimentos, incentivos ou parcerias comerciais ou políticas. As outras definem um conjunto de normas morais para todos que desejam participar das atividades do movimento.

\section{Estatuto dos seresteiros}

1. O Museu da Seresta, criação dos irmãos José Borges e Joubert de

Freitas, é mantido sem ajuda financeira de políticos e empresários;

2. O Museu não reivindica nem aceita colaboração financeira, não compra e não vende nada;

3. O Museu se propõe a preservar a memória da Música de Serenata, cantando pela rua, e do projeto "Em Toda Casa uma Canção";

\footnotetext{
${ }^{5}$ Adilon Alves Raposo é conservatoriano, um dos antigos seresteiros, que fez parte do movimento até o fechamento do Museu em 2009.

${ }^{6}$ Este texto encontra-se emoldurado e exposto na Casa da Cultura de Conservatória.
} 


\begin{abstract}
4. O Museu não tem representantes, nem vínculos políticos ou comerciais, admitindo solicitações dentro dos parâmetros do seu comportamento;
\end{abstract}

5. O Museu serve como ponto de encontro dos que cantam, tocam ou gostam de ouvir música de serenata;

6. O Museu não é casa de espetáculo e está aberto a todos os que cultuam a música popular brasileira, não importando se profissional ou amador, voz bonita ou não;

7. O Museu espera dos frequentadores a civilidade de um verdadeiro seresteiro: educação, disciplina, compreensão e nenhuma bebida alcoólica.

Com a constância e formalização as práticas se tornaram "de natureza ritual ou [e] simbólica, visando inculcar certos valores e normas de comportamento através da repetição" (HOBSBAWM, 1984, p.9). Além das serestas outra forma ritual, associada às serenatas, foi elaborada: o projeto "Conservatória, Em Cada Casa Uma Canção", idealizado por José Borges em 1958 e acolhido pelo grupo. A proposta inicial consistiu em confeccionar doze placas com nome de músicas e seus compositores; depois, afixadas em esquinas e locais de maior visibilidade. Deveriam ser músicas “que estavam na alma lírica do lugar, naquele momento.”. De acordo com os relatos de alguns entrevistados, "a comunidade ficou encantada, acolheu a ideia. Todos queriam uma plaquinha na sua casa". Assim sendo, o projeto "se expandiu [...]e então terminou com 403 placas, sem repetição de música; todas músicas brasileiras românticas". A intenção do projeto era: "preservar as canções de amor brasileiras cantadas em serenata, [e,] "que estão consagradas nas serenatas do lugar, e/ou têm um significado histórico-sentimental na vida do morador". (Joubert e José Borges). O projeto encerrou em 2003, ano após falecimento de José Borges. Posteriormente, houve pedidos para serem colocadas novas placas, mas por decisão da viúva com anuência do irmão e seresteiros, essa possibilidade foi negada.

Além das práticas musicais realizadas, o Museu foi recebendo diversos elementos que acabaram compondo um considerável acervo material, composto com: "matérias de jornais, revistas, fotos de visita de artistas, intelectuais e autoridades", como também livros, quadros, discos e outros objetos relacionados com música. (MAGNO, p.37).

Em 2002, José Borges veio a falecer e esse fato constituiu outro período de mudança substancial na história das serestas e serenatas de Conservatória. Embora muitos presumissem que Joubert, líder reconhecido tanto quanto o irmão, conseguisse dar prosseguimento a proposta de José Borges em manter sua residência como local de encontros dos seresteiros, não foi o que ocorreu. Aos poucos, mudanças foram sendo feitas pela viúva, em relação principalmente ao Museu, trazendo consequências para todo o movimento dos seresteiros. Conforme relatos e documentos, se iniciou um enaltecimento à José Borges, por 
parte da viúva, como fosse ele o único detentor das idéias e líder do movimento. Um desses feitos foi a confecção de uma estátua em sua homenagem, encomendada pela viúva, posta na Travessa Geralda Fonseca, de onde saem as serenatas todos os finais de semana. A estátua se tornou símbolo a mais na configuração de significados das serenatas.

O nome do Museu, com direção da viúva, teve alterações sempre incluindo apenas o nome de José Borges: Espaço Cultural José Borges e Instituto José Borges de Freitas Neto. Com essas divergências integrantes do movimento deixaram de participar das serestas, mantendo apenas a ida para as serenatas.

Após muitas divergências, a viúva, se sentindo afrontada por pessoas do local e até atacada pela mídia, fez publicar, em agosto de 2009, uma 'Carta Aberta aos Cidadãos de Conservatória', redigida por seu advogado, repudiando tais atitudes. Nesta carta destaco dois pontos. O primeiro diz respeito à denominação criada para a "propriedade que, por força do hábito, erradamente, convencionou-se chamar de museu", e que por não ter "inscrição no Instituto do Patrimônio Histórico e Artístico Nacional (IPHAN), não há como a propriedade receber, nem usar a denominação de museu, ...”. O segundo se refere à subjetiva reiteração de José Borges como principal articulador das idéias do movimento, e único responsável pelo custeio do Museu e da execução dos projetos por ele elaborados “... a singela ideia de José Borges, e posteriormente Joubert, ganhou forma, fama, e, até mesmo um acervo particular, os encontros musicais se disseminaram pela cidade, José Borges, num projeto de sua autoria e recursos próprios, distribuiu 403 (quatrocentos e três) placas com letras de músicas por diversos endereços da cidade". ${ }^{7}$

A leitura dessas divergências aponta para a dicotomia público e privado. Quando vivo, José Borges respondia por seu idealismo de preservação de uma tradição musical, liderava e podia manter o local; dele fazendo o que quisesse. O Museu era um espaço privado, porém, com significação e entendimento de espaço público. De acordo com relatos de dois entrevistados, ele tinha uma proposta de tornar a casa em uma fundação, mas seu inesperado falecimento levou na direção do que a casa era realmente, uma propriedade privada. Como tal, a proprietária tinha condições de aceitar ou não dar continuidade ao idealismo do falecido marido. No final de 2009, a viúva conseguiu um laudo pericial declarando a existência de problemas na estrutura da casa, apresentando riscos aos frequentadores. Assim, o Museu da Seresta e da Serenata, como continuou a ser chamado pela comunidade conservatoriense, encerrou as atividades. No entanto, o grupo de seresteiro deu continuidade às práticas, por algum tempo apenas da serenata, pois esta não necessita de espaço fechado para ocorrer.

Contudo, o fechamento do 'Museu' não encerrou as atividades do movimento seresteiro. Depois de algum tempo as reuniões passaram a ser desenvolvidas na Casa da Cultura de Conservatória; uma edificação em estilo neoclássico, construída entre 1820 e

\footnotetext{
${ }^{7}$ Destaque feito pelo próprio relator.
} 
1830, pelo Sr. Francisco de Leite Ribeiro, abastado fazendeiro do distrito. As serenatas continuaram saindo do mesmo local de quando existia o Museu.

É relevante citar que parte do acervo que ambientava o 'Museu' foi acolhido pela Casa da Cultura. Até final de 2015, ficou guardado em caixas numa sala da Casa da Cultura, quando o grupo dos seresteiros conseguiu com a administração municipal um espaço com três salas na atual rodoviária. Esse espaço, a rodoviária, constitui outro exemplo de elemento simbólico utilizado na contextualização local; especificamente referenciando a memórias e ao nacionalismo. A construção original era a estação ferroviária, que por ter sido inaugurada por D Pedro II, adquiriu categoria de símbolo, estimulando discursos de permanência, memória e preservação de patrimônios culturais. Em alguns eventos realizados no distrito, sejam relativos as serestas e serenatas ou de comemorações, a rodoviária é bastante utilizada como cenário.

O prédio se constitui de dois pavimentos e dois blocos, tendo no meio um espaço aberto, com alguns bancos de madeira e ferro, um relógio na parede e diversos painéis contando a história da ferrovia, da inauguração realizada por D. Pedro II e homenagens. Além de ser a rodoviária, também abriga, atualmente, a subprefeitura e a ACRITUR (Associação Comercial Rural, Industrial e Turística de Conservatória). Restaurada recentemente (2016), manteve o telhado colonial e acabamentos em ferro, sua forma original na parte externa.

O espaço criado e utilizado pelos seresteiros foi denominado Centro da Memória da Serenata de Conservatória. A sala principal foi destinada à homenagem aos irmãos Freitas. As outras duas comportavam várias documentações e objetos diversos oriundos do antigo museu. Contudo, a dificuldade de manter o espaço aberto à comunidade e aos turistas e a solicitação da administração local para abrigar a parte administrativa, fez com que o acervo retornasse à Casa da Cultura; mantendo o mesmo nome. Mas agora, esta disponibilizou uma pequena sala que fica à direita do salão onde ocorrem as serestas, deixando o acervo exposto ao público em mostruário, mesas, prateleiras e nas paredes.

Como uma espécie de saudosismo e preservação da memória do Museu, nas altas paredes do salão, onde ocorrem as serestas, foram afixados painéis e fotos, de forma bem semelhante a disposição antes existente no Museu da Seresta. São reportagens, fotos antigas, faixas com parte de poesias ou músicas, pinturas em cartolinas, poesias e canções sobrepostas numa folha de isopor com molduras de fitas laminadas. E também alguns objetos como antigas plaquinhas (do projeto "Conservatória, Em Cada Casa Uma Canção") e um "violão" artesanal. A edificação da Casa da Cultura é emblemática e contribui para desenvolver memórias e narrativas que consolidam o imaginário coletivo de Conservatória. A própria estrutura física em estilo neoclássico - portas e janelas grandes de madeira, pedras no alpendre e molduras das janelas, piso de tábuas, pé direito alto, sancas - atua como uma espécie de transposição ao passado para os visitantes.

$\mathrm{Na}$ conjunção das apresentações das serestas e as exposições podemos explorar a Casa da Cultura como mais um exemplo do contexto conservatoriano, para entender o que Ingold 
(2012) chama de malha ${ }^{8}$ (meshwork), ou teia. Cada elemento constituinte desse ambiente, na sua concepção 'coisa', é uma matéria, mas não uma matéria morta, mas que adquire vida à medida que "a vida dos habitantes (frequentadores) vai transbordando... (e) produzindo ecos de reverberação e padrões de luz e sombra característicos" (INGOLD, 2012, p.40), a partir dos movimentos, ritmos e sentimentos produzidos nas atividades humanas, registrados no ambiente. Ou seja, as coisas materiais se intercalam com música, sentimentos, ações, e tudo que envolve o espaço, formando um ambiente de fluxos que não se acaba.

\section{Os rituais das serestas e serenatas}

$\mathrm{Na}$ imaginação do visitante que vai à Conservatória pela primeira vez e sem informações prévias, as duas manifestações se confundem como fosse uma coisa só. Contudo, são categorias de distinção de espaços e formas de apresentação musical, que os seresteiros em Conservatória fazem questão de reiterar em cada apresentação. Essa distinção se convencionou entre os agentes do 'movimento seresteiro'9 de Conservatória a partir de uma palestra em 1988, em Conservatória, ministrada pelo radialista, pesquisador e compositor Paulo Tapajós (1913-1990). Ele assim designou: "A serenata é um concerto ao sereno. Esse mesmo tipo de concerto dentro de casa era o sarau. [...] A seresta é uma mistura do sarau com a serenata". Serenata deriva "do latim serenus, que tanto podia querer dizer céu sem nuvens, quanto calma e tranquilidade” (TINHORÃO, 2005, p.13). Daí resultou os nomes seresteiros, serenateiros, serenatistas e sereneiros, para intitular os cantores de modinhas (Ibdem, p. 14). Assim, a serenata é a manifestação que ocorre nas ruas, com um seresteiro ou um grupo de seresteiros, em geral tocando violão e cantando canções românticas. Já a seresta é um termo moderno, que se refere às cantorias realizadas em ambientes fechados: salões de clubes, hotéis, pousadas, bares, restaurantes - e pode exibir músicas com ritmos mais rápidos, como sambas-canções. Sendo realizadas em locais que não necessita de locomoção e possibilita o uso de instrumento musicais maiores e até amplificação sonora.

Para um melhor entendimento do que são essas manifestações descrevo sumariamente, conforme as etnografias realizadas no acompanhamento das práticas, nas diversas incursões ao campo, como elas operam atualmente. Inicio com as serestas pois elas são como uma espécie de ensaio para as serenatas, embora, nem todos agentes participem da segunda prática.

As serestas se iniciam na Casa da Cultura por volta das 20 horas. Aos poucos vão chegando seresteiros e visitantes. Sem aguardar mais componentes, os integrantes que tocam os instrumentos, em geral violões, passam a dedilhar e cantarolar músicas. Passado alguns minutos um integrante dá as boas vindas. Este pode explicar algum detalhe sobre a seresta,

\footnotetext{
${ }^{8}$ Termo que Ingold toma de empréstimo da filosofia de Henri Lefebvre (1991).

${ }^{9} \mathrm{O}$ grupo dos serenateiros se autodenomina como um movimento cultural. Em diversas entrevistas identifiquei o uso desse termo. "Mas quando eles (irmãos Freitas) chegaram aqui já encontraram esse movimento". "O movimento não mudou com a morte dos irmãos”.
} 
da serenata, a diferença entre elas, o que é movimento seresteiro, etc. Pode ainda pedir para prosseguir a cantoria e só falar sobre essas coisas depois; não existe roteiro prévio de apresentação das informações a serem divulgadas.

Não existe o reconhecimento explícito de uma liderança no grupo, ou uma titulação, para quem passa as informações e faz a chamada dos integrantes para cantar. Assim, para eles não é correto denominar esse integrante como condutor, dirigente, comandante ou líder. Comumente essa tarefa é de algum seresteiro mais antigo no movimento, ou, a quem o grupo concorde que faça a condução das apresentações. Embora alguns seresteiros sejam mais antigos, preferem se abster dessa tarefa e apenas cantam ou declamam. Apenas dois ou três integrantes tem exercido essa tarefa. Na verdade, esse integrante pode ser visto como uma espécie de oficiante ritualístico, quando através da comunicação e interação, exerce poder e sabedoria (TURNER, 1974, p. 127). Há sim uma hierarquia estabelecida a partir da experiência dentro do grupo, que é transmitida com histórias, poesias, mitos e músicas.

Existe uma norma na hora da apresentação que é seguir a ordem de chegada ao recinto. Se um integrante chegar depois, ele espera todos se apresentarem para então ter a vez. Cabe ao integrante que conduz fazer as apresentações e chamar cada integrante presente. A frequência dos seresteiros não é estipulada, como também não existe acordo prévio de quem vai ou não. Insisti em perguntar a diferentes integrantes e sempre obtive a resposta de que não há nenhuma combinação. Alguns são constantes, outros nem tanto, mas para ser seresteiro nesse grupo deve haver assiduidade regular. Como a maioria reside em outras cidades fica a possibilidade de não ter um número expressivo em uma seresta, mas sempre têm alguns seresteiros, principalmente dos que moram no distrito.

Em geral, quando se inicia a seresta é pequeno o número de visitantes presentes, mas, aos poucos o salão vai se enchendo e na maioria das vezes, ao chegar ao fim, alguns ficam em pé por falta de espaço e cadeiras. As apresentações transcorrem em clima de descontração e o que prevalece é a execuções das músicas, embora se declamem poesias e parte dos seresteiros relata episódios de suas vidas; histórias relacionadas com uma poesia ou música; histórias sobre os irmãos Freitas, histórias sobre Conservatória, crônicas ou algo que remeta sua presença ali. Além das histórias, fazem constantes brincadeiras entre eles e com os visitantes. "Aqueles que estão de pé aguardem que daqui a pouco teremos um rodízio", "Aqui nós encontramos a fonte da juventude! Voltem outras vezes que eu conto onde fica". Algumas histórias narradas são recorrentes, não sendo difícil para quem retorna ouvi-las de novo. Essas histórias, brincadeiras e piadas, entremeiam canções românticas, que inspiram saudosismo e lembranças. Há até sugestão do integrante que faz a condução para entrar no clima: "Eu quero que vocês viagem comigo, imaginando que estão num salão de bailes...”. (ao fundo um solo de violão tocando 'Eu sonhei que estavas tão linda').

Os seresteiros, seja na seresta ou serenata, expressam repetidamente não serem profissionais. Não é necessário ter voz bonita ou afinação para cantar. Para eles, a dedicação ao movimento é por amor a música romântica antiga e busca pela preservação desta. O que, com o tempo, se convencionou chamar de 'tradição'. É comum ouvir nas apresentações: 
“Aqui, todos cantamos". Até mesmo visitantes podem se habilitar a cantar ou declamar. Mas, tem uma exigência para os seresteiros e visitantes, que é citar os nomes dos autores da música ou da poesia. No entendimento dos seresteiros, essa é uma forma de valorizar e perpetuar os autores. Não importa ter habilidades musicais, mas o sentimento de pertencimento ao grupo e poder se expressar. A ênfase está na valorização da música romântica e seus autores, não nos intérpretes.

O ritual das serestas, como exposto anteriormente, difere das serenatas por ser realizado em um ambiente fechado, as músicas poderem ser num ritmo um pouco mais rápido e, também, pelo clima descontraído que a interação entre público e seresteiros permite. O encerramento ocorre por volta das $22 \mathrm{~h} 30 \mathrm{~min}$, para dar tempo aos que forem participar da serenata chegar ao ponto de partida da serenata.

Por volta de 22hs40 os seresteiros vão chegando na esquina da Rua Oswaldo Fonseca com a Travessa Geralda Fonseca, onde se inicia o cortejo das serenatas, desde a existência do Museu da Seresta e da Serenata. Nessa manifestação há um líder reconhecido por muitos como herdeiro da liderança do movimento de seresteiros, deixada pelos irmãos Freitas. $\mathrm{Na}$ ausência deste líder, a condução do cortejo pode ser realizada por outros integrantes mais experientes do grupo. Entre eles seresteiras que foram colaboradoras dos irmãos Freitas que participam das serenatas mais de vinte anos. A média de seresteiros que participam, sem ser dia de eventos especiais, é de cinco integrantes tocando violões, oito a dez cantores e alguns integrantes que auxiliam na passagem do cortejo. O público vai se aproximando aos poucos e assim que se inicia tomam parte do cortejo ouvindo as explicações, poesias, músicas e cantando junto com o grupo. A primeira dessas explicações se refere aos irmãos Freitas, a contribuição e criação deles nas práticas, indicando a estátua de José Borges, logo em frente o ponto de partida da serenata.

Independente da quantidade do grupo que esteja presente, a serenata se inicia sempre no horário estabelecido: às 23:00hs. O ritual começa com explicação, feita pelo condutor, da diferença entre serestas e serenatas e que "poesia e serenatas andam juntas". Essa é a forma de explicar porque, entre uma música e outra, são feitas declamações. As três primeiras músicas e poesias são nitidamente ritualísticas, pois só após elas, outras podem ser cantadas e outras poesias declamadas. O encaminhamento do cortejo obedece a "posições rituais" que também são posições de hierarquia (BITTER, 2008). Na frente se posiciona o condutor da serenata, detentor de poder e "conhecimento necessário para conduzir as ações do grupo e mediar todo tipo de situação", como por exemplo, o percurso a ser seguido, pedir silêncio aos visitantes ou qual música cantar (BITTER, 2008, p.37). Logo atrás vêm os outros seresteiros que acompanham o ritual. Em volta e mais atrás os visitantes, que cantam junto e param para ouvir informações e declamações. Uma ou outra vez quem declama também se posiciona na dianteira, e logo em seguida retorna a seu espaço. Na execução das músicas, o cortejo vai se movendo lentamente: são dados alguns passos e uma pequena parada, logo, outros passos e mais uma parada, até finalizar a música. O cortejo tem, atualmente, duração de aproximadamente uma hora e meia. Conforme relato de alguns interlocutores, 
anteriormente, costumava avançar pela madrugada. No percurso, aos poucos, visitantes vão deixando o cortejo, encerrando com número bem reduzido.

A quantidade de pessoas a seguir o cortejo varia de acordo com o final de semana e dia. Na sexta-feira essa quantidade não é tão expressiva quanto no sábado. Também aumenta consideravelmente, nos dois dias, quando tem algum evento ou comemoração especial. Nas sextas-feiras a média é de 70 e no sábado de 100 visitantes. A grande maioria desse público participante é de pessoas acima dos sessenta anos. Mas, também se podem ver vários adultos mais novos e também alguns jovens.

É compreensível a variação de faixa etária e o predomínio de idosos nesse tipo de manifestação, tanto quanto na seresta e no movimento dos seresteiros. São pessoas que, se não tiveram a vivência no período quando esse estilo musical fazia sucesso, aprenderam suas letras e melodias quando seus pais colocavam LP’s e rádios para ouvirem essas músicas, ou mesmo as cantavam. Uma característica desse estilo musical é justamente provocar sentimentos de saudades, trazer à tona essas memórias musicais. (HALBW ACHS, 2003).

As manifestações das serenatas e serestas realizadas em Conservatória, antes práticas de lazer, foram ao longo do tempo adquirindo novas significações. A criação de narrativas conjugadas com práticas rituais e simbólicas acabou por "inculcar certos valores e normas de comportamento através da repetição” (HOBSBAWM, 1984, p. 10). Também, estabeleceu certa continuidade, "artificial", com o passado histórico da expressão, usando "referências e situações anteriores” (HOBSBAWM, 1984 p.9).

A construção dessa expressão cultural opera com categorias que pretensamente pleiteiam um "resgate" do passado, tais como: memória, passado, patrimônio, perda, esquecimento e tradição. As narrativas dos agentes dessas práticas e suas elaborações têm o objetivo de tê-las como patrimônio cultural, ao menos enquanto "categoria de pensamento" (GONÇALVES, 2003).

Considerando o surgimento das serenatas em Conservatória pela citação no Almanach Laemmert, em 1878, essa expressão musical ultrapassa cem anos. Pode-se assim presumir que se tornou numa tradição popular local. Mesmo secular, somente agora, no século XXI houve interesse em solicitar ao IPHAN o reconhecimento das serenatas como patrimônio cultural intangível.

Com o passar do tempo outros elementos se somaram às serenatas, fazendo do distrito um cenário turístico musical do Estado do Rio de Janeiro. Por isso, a primeira tentativa de patrimonializar algo em Conservatória foi do Estado do Rio de Janeiro, com propósito a valorização do turismo. Em outubro de 2007, o deputado estadual Nelson Gonçalves, enviou o Projeto de Lei 1027/2007, propondo a criação do Pólo Cultural, Histórico e Turístico de Conservatória. O Projeto foi sancionado como Lei Estadual no 5564 , em 2009, pelo então governador Sérgio Cabral. Entretanto, sua aplicação não se tornou efetiva. O INEPAC (Instituto Estadual do Patrimônio Cultural), responsável por inventariar o Patrimônio e para fazer o reconhecimento não possuía mecanismos legais para tal. 
Em 2012, a Secretaria de Cultura do Município (Valença), se interessou em pedir a patrimonialização das serenatas. A Casa da Cultura entrou no processo como órgão solicitante e teve assim início a elaboração de um dossiê para submissão ao IPHAN. A reivindicação é para tornar a expressão musical das serenatas Patrimônio Cultural Imaterial. O dossiê foi enviado para análise em junho de 2014, fundamentado no artigo dois da Convenção Para a Salvaguarda do Patrimônio Cultural Imaterial (2003),

Entende-se por 'Patrimônio Cultural Imaterial' as práticas, representações, expressões, conhecimentos e técnicas - junto com os instrumentos, objetos, artefatos e lugares que lhes são associados - que as comunidades, os grupos e, em alguns casos os indivíduos reconhecem como parte integrante de seu patrimônio cultural. Esse patrimônio cultural imaterial, que se transmite de geração em geração, é constantemente recriado pelas comunidades e grupos em função de seu ambiente, de sua interação com a natureza e de história, gerando, um sentimento de identidade e continuidade, contribuindo assim para promover o respeito à diversidade cultural e à criatividade humana. (UNESCO, 2005).

Em novembro de 2016, o IPHAN retornou com um ofício solicitando informações mais detalhadas sobre alguns aspectos. Esse acontecimento foi considerado com positividade, por pressupor a possibilidade de análise e aceitação da proposta. Assim, reuniões foram realizadas com os "detentores da prática" 10, dando ciência dos questionamentos feitos pelo IPHAM. Entre as informações solicitadas encontramos: a realização de um mapeamento para dar ciência da importância da manifestação em Conservatória; caracterizar melhor a comunidade detentora do bem cultural imaterial; apresentar características do turismo no município e dos turistas; apresentar a relação entre a prática cultural e outras esferas do município; os aspectos geracionais e a transmissão de saberes relativo ao bem.

Após algumas reuniões, exclusivamente com agentes do movimento dos seresteiros, o Dossiê foi reenviado para apreciação. Ficou acertado que se houvesse um retorno positivo do IPHAN seria comunicado à toda comunidade conservatoriana. $\mathrm{O}$ fato de que apenas os agentes do movimento seresteiro puderam participar das reuniões denota parte de diversos outros conflitos que envolvem as serestas e principalmente a serenata. Entre eles a apropriação da denominação 'seresteiro de Conservatória'. O Movimento dos Seresteiros

\footnotetext{
10 O uso do termo "detentores" deriva inicialmente da reprodução do texto do dossiê de solicitação de patrimonialização das serenatas. A associação à "práticas" concerne e é substanciado pelo Conselho Nacional de Referência Cultural - CNRC, como os "sujeitos diretamente envolvidos na dinâmica da produção, da circulação e do consumo de bens culturais, reconhecendo-lhes o estatuto de legítimos detentores não apenas de um 'saber-fazer', como também o destino de sua própria cultura.” (Educação Patrimonial - Histórico, conceitos e processo, p. 7).
} 
considera seresteiro, ou serenateiro, como passaram a se denominar, apenas aqueles que seguem os padrões normativos criados pelos irmãos Freitas, do "Estatuto dos seresteiros". O dossiê foi reenviado para análise em 2017. Ressalto que até o envio deste artigo (início de 2019) ainda não havia retorno por parte do IPHAN.

Do que pude captar nas observações as que mais oportunizam divergências são: a não aceitação de ajuda financeira de políticos ou empresários; a não compra e nem venda de nada; não possuir representação política ou comercial que possam fazer solicitações; estar aberto a "todos os que cultuam a música popular brasileira, não importando se profissional ou amador, voz bonita ou não"; espera dos "frequentadores a civilidade de um verdadeiro seresteiro: educação, disciplina, compreensão e nenhuma bebida alcoólica”. Como se observa, a tônica do grupo é ser autônomo, não manter vínculos econômicos de nenhuma espécie. E também, se depreende das narrativas dos seresteiros o objetivo do movimento: a preservação das serenatas, principalmente, e das serestas.

Por vezes ouvi, no campo, posicionamentos e referências de se fazer das serenatas uma manifestação proporcionada de forma profissional ou institucionalizada, como uma associação. Algumas informações contam a intenção de comerciantes e outros agentes sociais de estabelecer Conservatória como a 'Cidade da Música'. Essa proposta é manifestadamente rejeitada pelos serenateiros e outros agentes de outros grupos musicais em Conservatória. Para tal, utilizam argumentos de que Conservatória não é cidade e essa denominação dá margem de entendimento a que possa haver manifestações de todo gênero musical, que retiraria a característica principal do vilarejo: a valorização da música romântica brasileira. De acordo com diversos interlocutores, o movimento seresteiro tem reconhecimento pela comunidade de ser a motivação da demanda turística, produzindo autoridade junto a ela para senão proibir, fazer crítica quando surgem ideias de inovações referentes às músicas estrangeiras.

Parte dessas colocações se deve ao fato do desenvolvimento e divulgação das serestas e serenatas, que tornou Conservatória um contexto turístico musical com um espaço amplo de disputas e o processo de apropriação das práticas musicais por grupo de empresários e comerciantes locais. As serenatas, serestas e outras dimensões culturais no contexto conservatoriano têm como agentes de apropriação simbólica os seresteiros e músicos. Estes se apropriam das expressões musicais, símbolos e rituais, resignificando as práticas em defesa de uma preservação cultural. Em contrapartida, toda construção, criação e ressignificações são apropriadas por agentes externos ao movimento, não só representados por empresários e comerciantes, mas também por instituições e poder público. Isto é, de um lado os idealistas, em defesa de uma memória musical, do outro, agentes que objetivam um desenvolvimento econômico (com o discurso de trazer benefícios para o distrito).

Ainda que as narrativas dos seresteiros reiterem o caráter idealista do movimento seresteiro, os fluxos de relações se alteraram. Isto é, o interesse postulado pelo grupo era da preservação pelo idealismo autorrealizável, sem preocupação com renovação do grupo e de critérios que permitissem reformulações que pusessem em cheque a autonomia do 
movimento controlado pelos irmãos. Atualmente ocorre nas atividades um compartilhamento de significações com o público, havendo uma transferência simbólica na responsabilidade da preservação. A participação de cada visitante, com suas memórias, na evocação e manutenção de lembranças impessoais, colabora para criar uma memória coletiva; elemento essencial nas narrativas do grupo (HALBWACHS, 2003). Isto acabou acarretando o compromisso de apresentações semanais e fomento da atividade turística.

As serenatas nos discursos dos agentes é patrimônio cultural, senão do país, do contexto conservatoriano. Quando me defrontei com essa concepção, percebi a necessidade de saber quais as "dimensões discursivas" sobre patrimônio operam nesse contexto. A primeira notadamente se depreende das narrativas dos próprios agentes quando se referem às práticas e encontram "'ressonância' junto a seu público" (CHAGAS, 2015; GONÇALVES, 2003). Esse patrimônio foi construído coletivamente envolvendo dimensões de poder e disputas manifestadas pelos atores; e dimensões poéticas e musicais que são a motivação das práticas, conferindo identidade ao grupo.

A trajetória da pesquisa, geradora desse artigo, descortinou um encadeamento de relações simbólicas, apropriações e disputas que foram percebidas gradativamente. A observação da manifestação das serenatas direcionou para outras perspectivas além dessas relações, gerando uma análise de toda ambientação construída coletivamente, que não envolveu somente as serenatas. O ponto focal de entendimento dessa construção foram as serenatas, e, portanto, todas as abordagens feitas se relacionam com elas, visto que é a referência simbólica do distrito e de outros processos que lá ocorrem.

Os contextos de serestas e serenatas constroem uma "ambiência sonora", sejam os espaços ao ar livre ou fechados (VEDANA, 2016). Uma ambiência que "partilha de sentidos, onde cores, sons e cheiros diversos" compõem um cenário de performances musicais variadas. Vedana utiliza essa expressão em estudos de espaços urbanos abertos, abrangendo sonoridades diversas que compõem o espaço: trânsito, vento, canto de pássaros, águas correndo, conversas, etc. Aqui utilizei um recorte mais amplo, ciente que cada espaço descrito possui elementos próprios, que formam um contexto no qual, materiais e sujeitos se integram compartilhando de fluxos e sentidos expressos nas práticas de cada grupo que os vivenciam.

As tradições das serestas e serenatas são manifestações ritualísticas na ambientação conservatoriana, construídas a partir de fatores associados e que conseguiram estabelecer uma dinâmica musical com outras expressões musicais. Entre esses fatores, as narrativas de valorização do passado e resgate de memórias é sem dúvida o que gerou a invenção dessa tradição cultural. Como toda tradição, se reinventa e elabora ressignificações dos elementos existentes ou de novos que são apropriados nessa ressignificação.

Um fator pouco explorado, reconheço, foi a divulgação pelos meios de comunicação de massa. Os rituais seresteiros já existiam quando os veículos de comunicação de massa iniciaram a divulgação de Conservatória como um lugar tranquilo para passear, apreciar a natureza (amplamente apropriada e ressignificada) e possivelmente ouvir um grupo de 
seresteiros tocarem e cantarem pelas ruas do vilarejo. Contudo, não há como negar que as encenações na mídia televisiva, a partir da década de 1970, engendraram novas construções, redimensionando as atividades. E hoje, com as mídias virtuais, a divulgação abrange mais pessoas e torna possível maior fluxo social envolvendo essas práticas.

\section{Referências Bibliográficas}

BITTER, Daniel. A bandeira e a máscara: estudo sobre a circulação de objetos rituais nas folias de reis. Rio de Janeiro: Tese - UFRJ, IFCS, 2008.

CHAGAS, Mario. Patrimônio, o caminho das formigas. In: Anais do Museu Histórico Nacional. Rio de Janeiro, no 47, p. 197, 2015.

GONÇALVES, José Reginaldo S. "O Patrimônio como categoria de pensamento". In: ABREU, Regina; CHAGAS, Mário (Org.). Memória e patrimônio: ensaios contemporâneos. Rio de Janeiro: DP\&A/FAPERJ, 2003.

GONÇALVES, José Reginaldo S. O mal-estar no Patrimônio: identidade. Tempo e destruição. In: Estudos Históricos. Rio de Janeiro, vol. 28 no 25, p. 211-228, janeiro-junho, 2015.

GRÜNEALD, Rodrigo A. Os 'Índios do Descobrimento': Tradição e turismo. Tese (Doutorado em Antropologia). Rio de Janeiro: PPGAS-UFRJ, 1999

HALBAWAHS, Maurice. A memória coletiva. Trad. Beatriz Sidou. São Paulo. Ed. Centauro, 2003.

HERSCHMANN, Micael. Ativismo musical e desenvolvimento local - $\mathrm{O}$ estudo de caso do circuito da seresta de Conservatória. In: CALABRE, Lia (Org.): Politicas Culturais: Pesquisa e formação, p.287. Rio de Janeiro: Itaú Cultural, 2012.

HOBSBAWM, Eric. Introdução - A invenção das tradições. In: HOBSBAWM, Eric; RANGER, Terence (orgs.): A invenção das Tradições. São Paulo. Ed. Paz \& Terra, 2017.

HUYSSEN, Andreas. Seduzidos pela memória. Rio de Janeiro, Ed. Aeroplano, 2000.

INGOLD, Tim. Trazendo as coisas de volta à vida: emaranhados criativos num mundo de materiais. Horizontes Antropológicos, ano 18, n.37, p.25-44, 2012.

Estar vivo: Ensaios sobre movimento, conhecimento e descrição. Petrópolis: Vozes, 2015.

IPHAN. RESOLUÇÃO nº 001, de 03 de agosto de 2006. Brasília: IPHAN, 2006.

IPHAN. Educação Patrimonial - Histórico, conceitos e processos. Brasília: IPHAN, 2014.

MAGNO, Marluce. Serenatas de Conservatória, um patrimônio cultural. Valença: Ed. Marluce Magno, 2014.

TAMASO, Izabela. Paradoxos da conservação patrimonial na cidade de Goiás. Trabalho apresentado na 26a Reunião Brasileira de Antropologia, Porto Seguro, 2008. Disponível em http://www.abant.org.br/conteudo/ANAIS/CD_Virtual_26_RBA/grupos_de_trabalho/tr abalhos/GT\%2037/izabela\%20tamaso.pdf.

TINHORÃO, José R. Os sons que vêm da rua. São Paulo: Ed. 34, 2005. 
TURNER, Vitor. O Processo Ritual: Estrutura e Antiestrutura. Petrópolis: Ed. Vozes, 1974.

UNESCO - Convenção - sobre a proteção e promoção da diversidade das expressões culturais. Paris: UNESCO, 2005.

VEDANA, Viviane. Territórios sonoros e ambiências: etnografia sonora e antropologia urbana. Revista Iluminuras, vol.11, n.25, 2010.

\section{Maria Gorett de Oliveira Silva de Castro}

É mestra em Ciências Sociais pela Universidade Federal Rural do Rio de Janeiro e professora de sociologia da rede pública de ensino do Rio de Janeiro.

Recebido em 08/01/2019

Aceito para publicação em 08/05/2019 